\title{
Negocjowanie ze strukturami przemocy
}

Strategie postkolonialne, wydane w 2011 roku przez Wydawnictwo Krytyki Politycznej, to zbiór dwunastu rozmów z Gayatri Chakravorty Spivak. Zgromadzone materiały są zapisami rozmów, wywiadów oraz debat z udziałem Spivak, które miały miejsce w latach 1984-1988. Dotyczą między innymi kwestii polityczności, reprezentacji, wielokulturowości, dyskursu i teorii krytycznych.

Gayatri Spivak to jedna z czołowych postaci teorii postkolonialnej. Jej prace In Other Worlds: Essays in Cultural Politics (1987), Outside in the Teaching Machine (1993), A Critique of Postcolonial Reason: Towards a History of the Vanishing Present (1999), Death of a Discipline (2003), Other Asias (2005) oraz wydana razem z Judith Butler Who Sings the Nation State? (2011) są jednymi z najbardziej wpływowych pozycji współczesnej humanistyki.

Wydanie Strategii postkolonialnych w Polsce w roku 2011 jest pod pewnymi względami symptomatyczne. Jak do tej pory, poza Orientalizmem Edwarda Saida, nie doczekaliśmy się przekładów najważniejszych pozycji z zakresu teorii postkolonialnej. Ukazały się wprawdzie tłumaczenia pojedynczych artykułów oraz wybranych książek Saida, Homiego Bhabhy czy Dipesha Chakrabarty'ego ${ }^{1}$, brakuje jednak nadal tekstów

1 Zob. E. Said, Orientalizm, tłum. M. Wyrwas-Wiśniewska, Poznań 2008; E. Said, Kultura i imperializm, tłum. M. Wyrwas-Wiśniewska, Kraków 2009; 
przełomowych, które zmieniły współczesną humanistykę, oraz późniejszych, pokazujących nowe kierunki rozwoju postkolonializmu.

Do tej pory w Polsce ukazało się tłumaczenie kilku esejów Spivak: Czy podporządkowani inni moga przemówić? ${ }^{2}$, Krytyka postkolonialnego rozumu: $w$ stronę zanikającej wspótczesności $i^{3}$ oraz Komparatystyka ekstremalna ${ }^{4}$. To niewiele, biorąc pod uwagę dorobek Spivak. Dziwi zatem, że jako pierwszą na polskim rynku zdecydowano opublikować dość marginalną książkę tej autorki. Strategie postkolonialne, w oryginale The Post-Colonial Critic: Interviews, Strategies, Dialogues pod redakcją Sarah Harasym, to pozycja raczej uzupełniająca. Wbrew tytułowi nie jest to również kompendium wiedzy na temat postkolonializmu ani teorii Spivak. To raczej praca przybliżająca postać hinduskiej krytyczki.

\section{Hinduska w świecie amerykańskiej Akademii}

Gayatri Spivak, jak sama mówi, należy do pierwszego pokolenia hinduskiej intelig-encji. Urodziła się w Kalkucie w 1942 roku, pięć lat przed uzyskaniem przez Indie niepodległości. Po ukończeniu studiów, na przełomie lat pięćdziesiątych i sześćdziesiątych, wyjechała do Stanów Zjednoczonych, gdzie pod kierunkiem Paula de Mana napisała doktorat. Następnie zajęła się przekładem O gramatologii Jacques’a Derridy, którą opatrzyła autorskim wprowadzeniem.

Pomimo pracy na innym kontynencie zachowała silne związki z Indiami. Równocześnie z badaczkami i badaczami skupionymi wokół powstałej tam w 1980 roku Subaltern Studies Group, Spivak wprowadziła do humanistyki pojęcie subaltern, najczęściej tłumaczone jako podporzadkowany/podporzadkowana, które jest obecnie jednym z kluczowych pojęć w analizie społecznych relacji władzy.

H. Bhabha, DyssemiNacja: czas, narracja i marginesy wspótczesnego narodu, tłum. T. Dobrogoszcz, „Literatura na Świecie” 2008, nr 1-2; H. Bhabha, Mimikra i ludzie: o dwuznaczności dyskursu kolonialnego, tłum. T. Dobrogoszcz, „Literatura na Świecie” 2008, nr 1-2; D. Chakrabarty, Prowincjonalizacja Europy: myśl postkolonialna i różnica historyczna, Poznań 2011.

2 G.Ch. Spivak, Czy podporzadkowani Inni moga przemówić?, tłum. E. Majewska, „Krytyka Polityczna” 2011, nr 24-25.

3 G.Ch. Spivak, Krytyka postkolonialnego rozumu: w stronę zanikajacej wspótczesności, tłum J. Margański, [w:] Teorie literatury XX wieku: antologia, red. A. Burzyńska, M.P. Markowski, Kraków 2007.

4 G.Ch. Spivak, Komparatystyka ekstremalna, tłum. D. Kołodziejczyk, „Recykling Idei” 2008, nr 10. 
W 1985 roku Spivak wydała jedną ze swoich najgłośniejszych prac, esej Can the Subaltern Speak?, w którym podważyła moralne prawo zachodnich intelektualistów do mówienia o podporządkowanych oraz w ich imieniu. Zarzuciła Zachodowi rasową oraz klasową ślepotę, dowodząc, że w zachodnim dyskursie intelektualnym grupy podporządkowane nigdy nie zdobędą reprezentacji ${ }^{5}$.

W Strategiach postkolonialnych mamy zatem do czynienia z Gayatri Spivak jako teoretyczką kultury i tłumaczką, z ugruntowaną już pozycją zawodową. Obserwując ją w trakcie dyskusji, widzimy, w jaki sposób Spivak analizuje i dekonstruuje kulturę Zachodu, a więc jak używa postkolonialnych narzędzi.

Możemy zobaczyć również, jak odnajduje się w świecie zachodniej Akademii oraz jak odbierana jest w Indiach. Niemal z każdej strony przebija wrażenie, że mimo sławy jest ona dla zachodnich intelektualistów osobą obcą, Hinduską z, jak jest to określone w Strategiach, „pieczątką Kalkuty”. W Indiach natomiast odbierana jest już jako Amerykanka. Wszędzie jest równocześnie wewnątrz i na zewnątrz.

Jej pozycja sprzyja spojrzeniu na Akademię z różnych perspektyw Hinduski, mieszkanki Stanów Zjednoczonych, akademiczki, cudzoziemki z zieloną kartą, filolożki, zaangażowanej krytyczki społecznej, słynnej profesorki. Jest, jak sama się określa, „postkolonialną Hinduską z diaspory, starającą się zdekolonizować świadomość" ${ }^{6}$. Ma również świadomość swojej władzy wynikającej z wysokiej pozycji społecznej amerykańskiej akademiczki.

Spivak uważa, że jej wybory intelektualne oraz polityczne uzależnione są od biografii. Status migrantki, kobiety z Trzeciego Świata i związane z tym dyskursywne oraz często bardzo namacalne wykluczenie, pozwalają jej spojrzeć na społeczne relacje władzy z perspektywy zarówno centrum, jak i peryferii. Jej szczególna pozycja daje również etyczne prawo do ich krytyki. W przytoczonych w Postkolonialnych strategiach rozmowach wielokrotnie porusza temat ograniczeń, z jakimi spotykają się obywatele krajów Trzeciego Świata. Opowiada o kłopotach z przemieszczaniem się, obowiązku wizowym oraz o tym, jak traktowana jest jako kobieta wykraczająca poza genderowe normy dotyczące wyglądu, zarówno w Indiach, gdzie szokują jej krótkie włosy czy strój, w jakim uprawia jogging, jak i w Stanach Zjednoczonych, które nie są przygotowane na

5 G.Ch. Spivak, Can the Subaltern Speak?, [w:] Marxism and the Interpretation of Culture, red. C. Nelson, L. Grossberg, Urbana-Chicago 1988.

6 Tejże, Strategie postkolonialne, red. S. Harasym, tłum. A. Górny, M. Kropiwnicki, J. Majmurek, Warszawa 2011, s. 89. 
Praktyka polityczna

opiera się na

nieustannym

dekonstruowaniu

własnego języka

i rozpoznawania w nim

struktur przemocy.

Społecznie

odziedziczyliśmy słownik

budowany na kulturze

patriarchalnej, naszym

zadaniem jest zatem,

według Spivak,

budowanie nowego

języka profesorkę noszącą sari. Na własnym przykładzie pokazuje, jak różne oblicza ma wykluczenie. Ta strategia ma określony cel: „zawsze czułam, że powinno się mówić z osobistego punktu widzenia. Co znaczy, że każdy powinien myśleć o sobie jako o jednostce publicznej. Nie chodzi o to, by zwierzać się z każdego fragmentu własnej intymnej historii, ale aby myśleć o przestrzeni reprezentacji, w jakiej się występuje”7.

W Strategiach Spivak jako profesorka często pytana jest o zaangażowanie środowiska akademickiego. Jak sama jednak mówi, nie wie, na czym miałaby polegać jej polityczna użyteczność poza zajęciami akademickimi. Jest sceptyczna wobec wykładowców akademickich twierdzących, że poprzez dydaktykę dokonują zmiany politycznej. Jej zdaniem nie mogą tego wiedzieć, pozostając w zamkniętym świecie Akademii. Spivak dość dosadnie określa te praktyki: „Krytycy literaccy i inni intelektualiści mają odruch ratowania mas, mówienia w ich imieniu, opisywania ich. A może nauczylibyśmy się mówić tak, by masy nie uznały tego, co mówimy, za pierdoły?”8.

\section{Negocjowanie jako strategia polityczna}

Spivak mówi, że praktyki polityczne są jak prace domowe. Wymagają konsekwencji i staranności. Nie da się przeprowadzić zmiany jeden raz i na zawsze. Podobnie w Akademii nie można przeprowadzić zmiany na jednym wykładzie. Praktyka polityczna opiera się na nieustannym dekonstruowaniu własnego języka i rozpoznawania w nim struktur przemocy. Społecznie odziedziczyliśmy słownik budowany na kulturze patriarchalnej, naszym zadaniem jest zatem, według Spivak, budowanie nowego języka.

Ważnym elementem politycznej strategii jest negocjowanie. Negocjacja tak, jak rozumie ją Spivak za Derridą, to nieustający wysiłek dyskursywny, aby na chwilę ustabilizować znaczenie. Jest to jednak również kategoria postkolonialna. Teoretycy pracujący w ramach tej teorii od początku próbowali opisać sytuację znajdowania się pomiędzy dominującymi narracjami. Dla postkolonializmu kluczowym zagadnieniem jest negocjowanie granic wiedzy, ich ponowne zaznaczanie i przesuwanie tych granic, które przyczyniają się do utwierdzania dominujących narracji. Postkolonializm interesuje również, w jaki sposób dokonuje się translacja wiedzy pomiędzy poszczególnymi wspólnotami i jak można zmieniać po foucaultowsku rozumiane granice wiedzy oraz władzy.

7 Tamże, s. 124

8 Tamże, s. 76. 
Według Spivak tylko negocjowanie ze strukturami przemocy, a więc zależnych od siebie kulturowej i ekonomicznej kolonizacji oraz fallocentryzmu, może doprowadzić do wzmocnienia własnej pozycji i dać możliwość interwencji w ramach istniejących struktur.

W Strategiach Spivak wiele miejsca poświęca gwałtownie rozwijającym się wówczas ruchom politycznym i intelektualnym, między innymi feminizmowi. Pokazuje przede wszystkim, że nie istnieje jeden kobiecy podmiot ani uniwersalny dyskurs feministyczny. Mówi o feminizmie w skali globalnej. Zwraca uwagę, że kobiety z Trzeciego Świata nie mogą otrzymać od kobiet z Pierwszego Świata żadnych skutecznych rozwiązań. Ich problemy nie są określane jako „problemy kobiece”, interesujące feminizm kulturowy. Sprawy, które ich dotyczą, na przykład patriarchalny system małżeństw, określane są jako lokalne, a tym samym nieuniwersalne.

W rozmowie pt. Krytyka postkolonialna Spivak analizuje akademicki feminizm i na przykładzie anglosaskich studiów literaturowych pokazuje, jak łatwo odgradza się on od rzeczywistości. Przyjmując pozycję niemocy wobec patriarchalnego liberalizmu, akademicki feminizm nie negocjuje swojej pozycji w ramach systemu. Do tego niezbędna jest jednak świadomość własnej politycznej i moralnej pozycji.

Spivak kwestionuje również próby formalnego dopuszczenia do głosu osób spoza grup dominujących, na przykład w debatach czy panelach. Każda próba wysłuchania przedstawiciela grupy podporządkowanej, na przykład kobiety z Trzeciego Świata, mówiącej jako reprezentantka wszystkich kobiet z Trzeciego Świata, to wymuszenie uogólnienia i zdystansowania się do siebie, a tym samym pozbawienie świadomości politycznej.

\section{Feminizm, marksizm, dekonstrukcja}

Jako teoretyczka Spivak porusza się głównie w obrębie marksizmu, feminizmu oraz dekonstrukcji. Choć sama wielokrotnie w Strategiach postkolonialnych deklaruje się jako marksistka, to będzie to marksizm zawsze poddany właśnie strategii negocjacji

Tym, co w odniesieniu do Trzeciego Świata ma dziś w szczególności do zaoferowania marksizm, jest zdaniem Spivak teoria kryzysu, przez „kryzys” rozumiejąca moment, w którym projekt podważa sam siebie, tak jak dzieje się to w sytuacji, gdy ruch kobiecy zaczyna podważać założenia feminizmu.

Spivak uważa, że marksizm, feminizm i dekonstrukcja powinny nawzajem zakłócać swoje działania. 
Teoria Spivak nie jest

tatwa ani dla akademików, ani dla ruchów społecznych. Jako teoretyczka Spivak

nie trzyma się ortodoksyjnie jednej teorii. Wychodzi poza ramy feminizmu, ruchów kobiecych, marksizmu, pokazując, że za każdym razem należy podchodzić do nich krytycznie, aby uniknąć pokusy tworzenia teorii totalizującej

Feminizm musi pomyśleć jednostkę ludzką utożsamianą z pracą w inny sposób niż poprzez definicję pracy wytwarzającej nadwyżkę wartości. Feminizm jest zaangażowany zarówno w antyseksizm, jak i w transformację świadomości poza projektem marksistowskim, czyli przekształcenie pracującego (lub pracującej) w bezwiedną produkcję kapitału. Dekonstrukcja jako krytyczny moment, uświadomienie katachrezy, przypomnienie o polityce otwartych celów albo też o polityce wielkich narracji, zależnie od tego, czego wymaga dana chwila, przypomina, że każda prawdziwie „kochająca” praktyka polityczna musi upaść pod ciężarem własnej krytyki ${ }^{9}$.

Wprowadzając wspomnianą już kategorię negocjacji, posługuje się również inną, kategorią podporządkowanego innego/podporządkowanej innej. Jest to według niej kategoria sytuacyjna, to znaczy niepodpadająca pod żaden rygor teoretyczny, w tym pod ścisłą analizę klasową. Wymaga ona nieustającego krytycznego czytania, albowiem z łatwością może zostać wykorzystana do odwrócenia uwagi od represyjności i dominacji systemu. Według Spivak, jeśli kategoria ta zostanie przejęta przez wysoko postawionych w systemie naukowców czy też burżuazję, nabierze zupełnie innego znaczenia. Jak przekonuje biorąc pod uwagę obieg uspołecznionego kapitału, nie można mówić o podporządkowanym innym w Pierwszym Świecie.

\section{Strategie Spivak jako program polityczny}

W okresie, gdy przeprowadzane były wywiady, w świecie zachodnim teksty Spivak były nowością, wymagającą tłumaczenia i komentowania. Następowało to w toku dyskusji, stąd też prawdopodobnie wiele wątków przedstawionych jest w Strategiach pobieżnie lub też bez uprzedniego wyjaśnienia.

Teoria Spivak nie jest łatwa ani dla akademików, ani dla ruchów społecznych. Jako teoretyczka Spivak nie trzyma się ortodoksyjnie jednej teorii. Wychodzi poza ramy feminizmu, ruchów kobiecych, marksizmu, pokazując, że za każdym razem należy podchodzić do nich krytycznie, aby uniknąć pokusy tworzenia teorii totalizującej. Krytykuje również większość popularnych działań, szczególnie związanych z reprezentacją i praktykami oddawania głosu. Według niej, jakkolwiek staralibyśmy się przekazywać głos innych, będziemy ich jedynie reprezentować, mówić jednak będziemy zawsze wyłącznie własnym głosem.

\footnotetext{
9 Tamże, s. 146.
} 
Spivak nie daje również rozwiązań w postaci spójnej strategii działań. Mówiąc o polityczności języka, sama posługuje się językiem skomplikowanym, miejscami niejasnym i nasyconym metaforyką, za co wielokrotnie była krytykowana. To zresztą jedna z cech charakterystycznych wielu tekstów postkolonialnych końca dwudziestego wieku, próbujących wyjść poza ograniczenia języka oraz teorii i opisać sytuację znajdowania się pomiędzy czy też na marginesie dominujących narracji.

Strategie postkolonialne doskonale pokazują również, że postkolonializm jest raczej sposobem czytania, niż jednolitym nurtem. Dostajemy w tym wypadku przykład, jak wówczas, w latach osiemdziesiątych ubiegłego wieku, postkolonializm czytał zachodnią kulturę i jak, mówiąc językiem Spivak, negocjował z nią i używał jej narzędzi.

Strategie postkolonialne są w pewnym stopniu książką (już) historyczną, co widoczne jest w tekście. Wszystkie zamieszczone wywiady przeprowadzane zostały prawie trzydzieści lat temu. W tym czasie żyli jeszcze Jacques Derrida i Michel Foucault, których prace były na bieżąco komentowane, co znajduje odzwierciedlenie również tutaj. Rozmówcy Spivak wielokrotnie pytają ją o podstawowe pojęcia dekonstrukcji oraz samego Derridę. Tytułowe postkolonialne strategie poznajemy zatem w kontekście dyskusji nad teorią dekonstrukcji i jej znaczeniem oraz politycznym potencjałem.

Współcześnie kontekst zagadnień, które porusza Spivak, znacząco się zmienił. Mamy do czynienia z innym uniwersytetem, którego tradycyjna rola skończyła się, a także z inną krytyką literacką i społeczną. Zmieniły się również teorie, o których mówi Spivak, przede wszystkim feminizm i marksizm. Inne zagadnienia, które omawia, jak postmodernizm jako nurt kulturowy, dawno zeszły ze sceny.

Zmienił się wreszcie sam postkolonializm, podejmując częściej niż kwestie kulturowe problem relacji ekonomicznych oraz związanych z nimi kolonizacji i wyzysku. Współczesny postkolonializm powraca do antykolonianych źródeł, rozwijając silny podmiot sprawczy, przeciwstawiający się wyzyskowi ${ }^{10}$. W miejsce pojęć z teorii Foucaulta weszły pojęcia oporu, sprawczości i praktykowania wolności ${ }^{11}$. Podkreślenie podmiotu sprawczego [agency] związane jest z wpływem, jaki na postkolonializm wywierają krytyki związane równocześnie z kolonizacją

10 Zob. Ch. McEwan, Postcolonialism and Development, London-New York 2009.

11 E. Domańska, Badania postkolonialne, [w:] L. Ghandi, Teoria postkolonialna, tłum. J. Serwański, Poznań 2008, s. 159. 
kulturową i międzynarodowym podziałem pracy $^{12}$. Postkolonializm powraca do marksistowskich źródeł, pokazując, jak globalny kapitalizm na całym świecie czerpie z wyzysku skolonizowanych: pracujących dzieci, kobiet i mężczyzn. Współcześni skolonizowani to zarówno dzieci pracujące za grosze w azjatyckich fabrykach, nielegalnie pracujące w Europie Ukrainki, jak i Polki i Polacy funkcjonujący w warunkach niestabilnego zatrudnienia.

Szczególnie inspirująca staje się teoria Louisa Althussera, pod wpływem której wykształca się pojęcie postkolonialnego podmiotu interpelowanego lub też „obdarowanego ideologią" ${ }^{13}$. W postkolonializmie, mimo iż podmiot jest zdominowany, jest równocześnie aktywny, szukający możliwości wyzwolenia z opresji. Dlatego tak ważne jest tu budzenie świadomości klasowej. Jest to bezpośrednie odwołane do tradycji Franza Fanona, dowodzącego, że dopiero w obliczu konfrontacji z kolonizatorem skolonizowany uświadamia sobie, jakiej przemocy był poddawany oraz że musi na nią odpowiedzieć poprzez atak ${ }^{14}$.

Wprawdzie elementy tych zagadnień pojawiają się w zaprezentowanych w Strategiach postkolonialnych wywiadach, jednak są one jedynie zasygnalizowane, aby po chwili ustąpić miejsca tematom, które interesowały czytelników w latach osiemdziesiątych - dekonstrukcji czy postmodernizmowi.

Mimo to wiele wątków poruszonych przez Spivak i jej rozmówców zachowuje aktualność. Jej postkolonialne spojrzenie na konstruowanie podmiotowości indywidualnej i zbiorowej może być inspirujące dla wielu ruchów społecznych. Pokusa budowy totalizujących ruchów jest duża, zarówno w głównym nurcie, jak i poza nim. Najlepszym dowodem na to jest wciąż funkcjonujące w dyskursie publicznym esenjonalizowanie kobiecości, które obserwować możemy w dzisiejszej Polsce przy próbach stworzenia reprezentacji politycznej wszystkich kobiet. Ciągle brakuje nam również spojrzenia na globalne relacje władzy z perspektywy kobiet z Pierwszego i Trzeciego Świata czy też włączenia skali globalnej do mówienia o kapitalizmie.

Tłumaczenie prac Spivak to z pewnością translatorskie wyzwanie. Być może jednak warto to robić. Językowi polskiemu, uwięzionemu

12 N. Larsen, Marxism, Postcolonialism, and The Eighteenth Brumaire, [w:] Marxism, Modernity and Postcolonial Studies, red. C. Bartolovich, N. Lazarus, Cambridge-New York-Melbourne-Madrid-Cape Town-Singapore-Sao Paulo 2002, s. 215.

13 Tamże, s. 205.

14 F. Fanon, Wyklęty lud ziemi, tłum. H. Tygielska, posł. J.P. Sartre, Warszawa 1985. 
pomiędzy rasizmem a polityczną poprawnością, brakuje słownika politycznej manifestacji. Mówienie o byciu czarnym/czarną, brązowym/ brązową, białym/białą ma polityczną moc i prędzej czy później również w Polsce będziemy musieli nauczyć się odczytywać ten przekaz. Gdy Gayatri Spivak, profesorka uniwersytetu Columbia, mówi „Jestem brązową kobietą", dokonuje interwencji w dominującym dyskursie i wyraźnie określa swoją pozycję w strukturze klasowej, płciowej oraz rasowej.

Gayatri Spivak to współcześnie jedna z najbardziej wpływowych krytyczek kultury. To również jedna z pierwszych kolorowych kobiet, która zrobiła karierę w zachodnim świecie nauki. Wydanie tłumaczenia Strategii postkolonialnych może znacząco wpłynąć na odbiór prac Spivak w Polsce, szufladkując ją jako krytyczkę z lat osiemdziesiątych. To tłumaczenie spóźnione o dwadzieścia lat. Trzymając się programu minimum, można oczywiście stwierdzić, iż dobrze, że cokolwiek zostało przetłumaczone. Warto jednak pamiętać, że bez systematycznego upowszechniania prac teoretyków i teoretyczek postkolonialnych pozostajemy wciąż na marginesie dyskursu postkolonialnego.

Recenzja książki G.Ch. Spivak, Strategie postkolonialne, red. S. Harasym, tłum. A. Górny, M. Kropiwnicki, J. Majmurek, Warszawa 2011. 
MONIKA POPOW - doktorantka w Zakładzie Studiów Kulturowych i Filozofii Wychowania Instytutu Pedagogiki Uniwersytetu Gdańskiego. Animatorka społeczna oraz autorka programów edukacyjnych z zakresu przeciwdziałania wykluczeniu społecznemu oraz wyrównywania szans edukacyjnych. Współautorka książki „Idealna. Od poradnika do dialogu” (2012), współredaktorka książki „Oblicza biedy we współczesnej Polsce” (2011).

Dane adresowe:

Instytut Pedagogiki Uniwersytetu Gdańskiego

ul. Bażyńskiego 4

80-952 Gdańsk

e-mail: monika.popow@gmail.com

\section{Cytowanie:}

Monika Popow, Negocjowanie ze strukturami przemocy „Praktyka Teoretyczna” nr 1(7)/2013, http://www.praktykateoretyczna.pl/PT_ nr7_2013_NOU/17.Popow.pdf (dostęp dzień miesiąc rok)

Author: Monika Popow

Title: Negotiating with the structures of violence 